\title{
Gender Discrimination in Indonesian Literature Works: A Case Study of Translation
}

\author{
Nunun Tri Widarwati ${ }^{1}$, M. R. Nababan ${ }^{2}$, Riyadi Santosa ${ }^{3}$, Sri Samiati Tarjana ${ }^{4}$ \\ Universitas Sebelas Maret, Indonesia ${ }^{1,2,3,4}$ \\ Email Correspondence: nunun6323@gmail.com
}

\begin{abstract}
\section{Background:}

Although many kinds of research on gender discrimination have been made, empirical research on this matter under the perspective of translation technique is still rare. Therefore, this present research aimed to study gender discrimination in three novels authored by Pramoedya Ananta Toer and how gender discrimination is translated into English.

\section{Methodology:}

This case study was applied in three novels written by Pramoedya Ananta Toer, Anak Semua Bangsa, Rumah Kaca, and Jejak Langkah. The data were collected through observations and Focus Group Discussion (FGD). The data were analyzed using thematic analysis.

\section{Findings:}

The results showed that gender discrimination in the three novels was subordination, stereotype, marginalization, workload, and violence. Gender discrimination is translated using established equivalence, explicitation, modulation, paraphrase, implicitation, addition, transposition, reduction, compensation, discursive creation, pure borrowing, deletion, generalization, and particularization.

\section{Conclusion:}

This research reveals that gender discrimination is a phenomenon that commonly occurs in the world community. The research implications are also discussed either empirically or practically at the end of this article.
\end{abstract}

Keywords: case study; gender discrimination; Indonesia; literary works; translation technique.

DOI $\quad$ : http//dx.doi.org/10.24903/sj.v6i2.740

Received : June 2021

Accepted $\quad$ : August 2021

Published : October 2021

Authors retain copyright and grant the journal right of first publication with the work simultaneously licensed under a Creative Commons Attribution 4.0 International License that allows others to share the work with an acknowledgment of

Copyright Notice
: the work's authorship and initial publication in this journal. 


\section{INTRODUCTION}

For several decades, women's issues have been of great interest in novels as literary works. They have often been portrayed as inferior, weaker than men, and could not survive and work independently. In Egypt, Suwaed (2017) reported that the oppression and exploitation of Arabic women through gender discrimination, social inferiority, sexual oppression, girls' circumcision, sexual exploitation, and rape persist relying on religion, tradition, and the regime within Arabic society in the wake of the Arab Spring. He argued that social processes are caused and led by those who recognize injustice and have the will and the drive to change things. Alice Walker, an Afro-American writer, argued the need for black women to gain their freedom. It is due to the black women being suppressed in many aspects and even misrepresented in their communities (Suresh \& Anuradha, 2018). The women were oppressed socially, physically and sexually, and also treated as slaves. Harriet Beecher Stowe in the United State of America wrote 'Uncle Tom's Cabin' and Mulk Raj Anand's 'Untouchability' to describe social discrimination such as racial, color, caste, and gender. She exposed these social problems to make people seriously think about eradicating such discrimination (Kadhim, 2018). Those empirical evidence showcase that the issue of gender discrimination has consistently received more attention from novelists around the world. The aim is to make the global readership comprehend that gender discrimination still occurs in their country and expect that men and women could get the same rights without any prejudice in all fields of their lives.

A growing body of empirical research has explored gender discrimination in literary works in Indonesia and has been of particular concern to the issue (Arbain, 2020; Agustin \& Putri, 2019; Astuti, Mulawarman, \& Rokhmansyah, 2018; Astuti et al., 2018; Hafid, 2017; Rahman, 2016; Rejo, 2012; Sari, 2019; Setyorini, 2017; Unsriana, 2014). In this regard, only Wang \& Chen's (2020) research discusses the relationship between gender and translation in novels. They indicate that translators have several tools at their disposal for negotiating and repressing excessive patriarchal gender prejudices in translated materials. For instance, when discussing the stereotype of women in the 1960s and 1970s Chinese-to-modern English novel Shuihu Zhuan, which is rooted in traditional Chinese cultural values of Confucianism in China, the translator attempts to translate the text in the most effective manner possible to bridge the gaps in gender ethics across languages and cultures. This is undoubtedly intended to harmonize the understanding of foreign readers who are less receptive to ethnic, racial, or sexual discrimination. However, no study examines gender discrimination in the novels Anak 
Semua Bangsa, Rumah Kaca, and Jejak Langkah from translation technique perspective to the novel discussed. Likewise, a large volume of empirical study examines Pramoedya Ananta Toer using various perspectives, but the issue of gender discrimination in the novels of Anak Semua Bangsa, Rumah Kaca, and Jejak Langkah still receive little attention (Badio, Nurgiyantoro, \& Hartono, 2019; Bagtayan, 2021; Farhana RM \& Aflahah, 2019; Kholifatu \& Tjahjono, 2020; Nursiah \& Liusti, 2020; Risnawati, Anshari, \& Abidin, 2017; Sariban \& Marzuqi, 2015; Sulaeman, Rohim, \& Muttaqien, 2020; Wicaksono, 2018; Winusari, 2019).

To bridge this void, the present study examines how women's discrimination is articulated in the novels and how translators bridge the language and cultural divide when trying to deal with such discrimination. Thus, two questions are addressed in this study: how is the expression of gender discrimination articulated in the novel? How is gender discrimination in the novel translated into English?

This empirical evidence contributes both empirically and practically. Empirically, this research provides new insights into how gender discrimination in the novels is translated using translation techniques. It means that any translation technique used by the translators can be identified. So, novice translators can apply accurate translation techniques and avoid which inaccurate techniques are used in translating texts containing gender discrimination expressions. Practically, translators are required to always translate gender discrimination issues accurately, acceptably and understandably by readers. Likewise, in the context of teaching translation, teachers are required to fairly act to their students in assessing their assignments without any distinction in terms of gender.

\section{METHODOLOGY}

This research adopted a translation case study design. A case study was employed since this research examined three novels written by Pramoedya Ananta Toer translated into English, such as Anak Semua Bangsa, Rumah Kaca, and Jejak Langkah. The three novels studied are his well-known works since they describe gender discrimination during colonialism, particularly in the Javanese community. The novels were chosen since they brought up gender discrimination among readers all over the world. To obtain data, the researchers made in-depth observations. We studied and explored expressions containing gender discrimination in the novels in the source or target language. The next step was to diversify the data by expert informants and raters amounting to 3 persons. It is aimed at conforming perceptions through Focus Group Discussion (FGD). This FGD is intended to make data not only accurate but also reliable. After being diversified, the authors and the 
raters determined the translation techniques adopted by the translators in translating the ST into the TT. In this case, the quantification of the percentage was also conducted to help explain the linguistic phenomenon that occurred. Then, the data analysis was thematically done by using Handayani's (2006) concept on gender discrimination and Molina \& Albir's (2002) translation techniques.

\section{FINDINGS}

\subsection{Expressions of gender discrimination in the novels}

The results of the FGD revealed that there were 4 expressions of gender discrimination in the novels namely subordination, stereotype perspective, marginalization, workload, and violence. The frequency of subordination was 42, stereotype perspective, 25 , marginalization 3 , workload 3 , and violence 2 . The percentage of the frequency is presented in Table 1.

Table 1. Expression of gender discrimination

\begin{tabular}{llll}
\hline No & Type of discrimination & number & Percentage \\
\hline 1 & Subordination & 42 & $56 \%$ \\
\hline 2 & Stereotype perspective & 25 & $33.33 \%$ \\
\hline 3 & Marginalization & 3 & $4 \%$ \\
\hline 4 & Workload & 3 & $4 \%$ \\
\hline 5 & Violence & 2 & $2.66 \%$ \\
\hline & Total & 75 & $100 \%$ \\
\hline
\end{tabular}

Although the number of data of the gender discrimination is lower than that of the social class, the type of discrimination in the gender discrimination expressions is higher in number. However, the composition of the comparison of the number of emergence among the type of discrimination is not far different from that found in the social class discrimination. For instance, subordination still becomes the type of discrimination that is most dominant. It is also the case for the type of stereotype perspective that occupies the second rank in the two categories of this discrimination. The marginalization, workload, and violence are not too high, either at social class or gender discrimination. This shows that the power relation between the powerful and the weak is the primary source of social class or gender discrimination.

\subsubsection{Subordination}

Subordination in gender discrimination refers to the view that gender is higher or more powerful than another gender. In the Javanese community, men always become the dominant gender while women are the second-class community in the gender discourse. 


\section{Example 1:}

“...While a mother, once her baby starts crawling, returns to become the maid for her husband....."

Example (1) clearly describes the women's position compared with men's in the Javanese society. Men are the dominant gender in Javanese society. They are leaders either in the community environment or in the family. Women are a second-class community, even in the family. This expression shows that women as wives should devote themselves to their husbands. It was different from men's position in the Dutch family in this Archipelago at that time. Although in the Dutch government, women were not as strong as men were, the position of men and women was equivalent in the family. It was what Minke admired from the white color culture. He hated a practice that women should devote to men in households like a maid to an employer. This phenomenon is the description of the women's position as the men's subordinates in the Javanese community.

\subsubsection{Stereotype}

In the gender discourse, a stereotype perspective is a label given to or inserted in a particular gender. The label given tends to be negative. In the context of the Javanese community, women often become labelling object. But, it is also possible that this labelling is also given to men. Because men hold a more dominant power than women in the Javanese community, women often become the victim of negative stereotypes.

\section{Example 2:}

"Anyhow, an indigenous girl will finish everything if she has married."

Statement (2) is an opinion made by a friend of Siti Soendari's father, a wife of the Resident of Pekalongan who was given a task to match her with a man. Siti Sundari is a female activist, the daughter of the mayor of Pemalang, who was trying to fight against any oppression made by the white to the indigenous. Her ideas and orations greatly disturbed the government officials. The colonial government tried to silence her through planned marriage. The wife of the resident of Pekalongan was given a task to persuade Siti Soendari. The statement made by the wife of the resident of Pekalongan contained a stereotype that a woman would not "act" after marriage. The view was a stereotype that Siti Soendari even fought against through her writings and orations which were very brilliant and were acclaimed by many people. 


\subsubsection{Marginalization}

Marginalization in gender discrimination occurred in the exclusion one of the genders from community activities since it was considered that the gender was inappropriate with or inadequate to take part.

\section{Example 3:}

"“'Why has the Netherlands up to now remained to close opportunities for women to become ministers or members of Tweede Kamer?"

Statement (3) is the question asked by Minke to his white colour fellow. Although the Dutch and Europeans, in general, were considered to be more civilized and to more respect women's rights, in fact, however, certain positions in the society were still dominated by men and were forbidden for women. The Minke's statement contains a presupposition that in the Dutch, women could not hold certain positions. The positions of ministers and Tweede could not be occupied by women. In Minke's imagination, Marginalization merely occurred in the Dutch East Indies, but it also happened in the colonial country that claimed to be more civilized.

\subsubsection{Workload}

Workload between men and women are often distinguished in the society. Women regarded as weaker creatures than men in general got a lighter portion of work. But, it often happens in the Javanese community, in the family that women have more house chores than men do. The following example shows a phenomenon of workload division which was imbalanced between men and women.

Example 4:

In villages, they worked as hard as men, but women should work harder since they should also take care of households and also children ....

Example (4) shows the condition of workload division between men and women in the family in the Javanese community. It is stated that women's work was as hard as men's. Men in the Javanese community are in charge of making a living, while women sometimes should also help their husbands to earn a living. This does not end. Women should also be responsible for taking care of house cleaning, their children, and their parents. It is stated before that in the life of a family, women were becoming maids for their husbands. 


\subsubsection{Violence}

Violence in the relation between men and women in the community was aroundphysical violence and included men's treatment of women or vice versa. In the context of Javanese community, since men occupied a more powerful position in the community than women, the men tended to do violence to women. The following is presented an example of how men treat women in the Javanese community.

\section{Example 5:}

.... Women should be silenced by marrying them.

Expression (5) is a criticism presented by Minke regarding how the men stopped women's voice in the government of the national revival movement. In the case that occurred to Kartini from Jepara, her father and the colonial government silenced the voice of "Kartini" by marrying her, although it was contradictory with her desire. Such a forced marriage is a phenomenon that often happened in the Javanese community. It is violence against women. Although it was not physical violence, but this kind of violence colonized the women's freedom and dignity in society.

\subsection{Translation techniques of gender discrimination in the novels}

Gender discrimination does not only happen in reality but also the world of nonreality. The world of non-reality may be described through novels, short stories, films, and the like. In the context of translation, there were 14 translation techniques in expressions containing the gender discriminations elements. The applied techniques had different distributions and frequencies. The established equivalent was the most used dominant translation technique. Meanwhile, particularization was the translation technique with the lowest frequency. The following is presented the frequency of translation techniques applied in translation expressions containing gender discrimination.

Table 2. Translation techniques applied in the expressions containing gender discrimination

\begin{tabular}{llll}
\hline No & Translation Technique & number & Percentage \\
\hline 1 & Established Equivalent & 308 & $65.53 \%$ \\
\hline 2 & Explicitation & 50 & $10.63 \%$ \\
\hline 3 & Modulation & 49 & $10.42 \%$ \\
\hline 4 & Paraphrase & 14 & $2.97 \%$ \\
\hline 5 & Implicitation & 9 & $1.91 \%$ \\
\hline 6 & Addition & 9 & $1.91 \%$ \\
\hline 7 & Transposition & 8 & $1.70 \%$ \\
\hline 8 & Reduction & 6 & $1.27 \%$ \\
\hline 10 & Compensation & 6 & $1.27 \%$ \\
\hline
\end{tabular}




\begin{tabular}{llcc}
\hline No & Translation Technique & number & Percentage \\
\hline 11 & Pure Borrowing & 2 & $0.42 \%$ \\
\hline 12 & Deletion & 2 & $0.42 \%$ \\
\hline 13 & Generalisation & 1 & $0.21 \%$ \\
\hline 14 & Particularisation & 1 & $0.21 \%$ \\
\hline & Total & 470 & $100 \%$ \\
\hline
\end{tabular}

\subsubsection{Established Equivalence}

Established equivalence was a translation technique mainly applied in translating expressions containing gender discrimination. It was applied 305 times from the total number of 470 times or $64.89 \%$. The followings are three data applying this translation technique in one of the parts of expressions containing gender discrimination.

Example 6:

SL: Dan, apakah nasib wanita Tionghoa sama buruknya dengan wanita sebangsanya? TL: And was the fate of women in China as terrible as it was for Javanese women?

The expression example (1) shows that the phrase 'as terrible as' is translated into 'sama buruknya'. The word functioning as an adjective in Indonesian is also translated using an adjective. In the context of TL, the meaning 'as terrible as' is equivalent to 'sama buruknya' in SL, describing whether women were treated the same as men in the Chinese people's culture in Indonesia at that time. The translation technique by taking the words with the meaning appropriate to the context is called established equivalence. This translation technique is adopted when there is a term with high similarity of meaning in the target language.

\subsubsection{Explicitation}

This translation technique was applied 50 times in expressions showing gender discrimination. This includes $10.63 \%$ of the total number of translation techniques in this category. Explicitation is intended to make a translation easier to understand or to omit any ambiguity. The following is two data applying the explicitation technique.

Example 7:

SL: “Anak-anak pembesar Pangreh Praja tak suka jadi dokter, pada pekerjaan mengabdi kemanusiaan. Mereka lebih memilih pekerjaan memerintah, menguasai, menjilat, terutama dijilat."

TL: "Service did not generally wish to become doctors or engage in work that involved working for one's fellow human beings. They preferred to govern, to wield power, to toady, and most importantly, to be toadied." 
The word 'and' in the TL served to connect some "to infinitives" in the sentences. In the SL, this conjunction does not exist. The translator brings up this word to make explicit the additional relationship among some constituents in the TL. Explicitation technique serves to explicitize the relationship among some components in the TL, which is implicit in the SL.

\subsubsection{Modulation}

Translation technique modulation was applied 49 times or $10.42 \%$ from the total number of data on the expressions containing gender discrimination or this technique, in general, is used to improve translation acceptability. It is obligatory in certain cases but may also be optional in other cases. The followings are some examples of data applying modulation translation techniques.

Example 8:

SL: "Sekiranya aku dahulu menikahi pribumi, tentu perhatianku tidak akan tertuntut terhadap segala tetek bengek begini."

TL: "Had I married a Native woman, I would never had to worry about any of this non sense."

A modulation technique applied in the above translation is applied by changing the point of view of case of 'segala tetek bengek' which is translated into 'any of this non sense.' In the ST, 'segala tetek bengek' functions as the (perpetrator) object with the subject of 'perhatianku' in the passive voice. Meanwhile, in the TL, 'any of this nonsense' serves' as the accompanying object in the passive sentence.

\subsubsection{Paraphrase}

This paraphrase technique was applied 14 times or $2.49 \%$ of the total number of translation techniques used in the data on expressions containing gender discrimination. Paraphrase tries to retell the message in the ST into the one in the TT in a different way. The following is presented the data applying this technique.

Example 9:

SL: “Apakah poligami juga merajalela?

TL: "Was there polygamy everywhere?

In the example above, the paraphrase technique is applied at the sentence level. Minke stated this expression to indicate how indigenous women were not treated equally and served as lust graters occurring massively in the society. This description in Indonesia is expressed with the word 'merajalela.' In English, this kind of sentence is expressed using a different way to fulfill the acceptability aspect to become "was there polygamy 
everywhere? which means "Apakah poligami terjadi di mana-mana?" if is is backtranslated.

\subsubsection{Implicitation}

Implicitation is a translation technique applied by making information in the ST not appear verbally in the TT but implicitly in the message. This translation technique was applied four times in expressions containing gender discrimination. This total number includes $1.91 \%$ of the total number of translation techniques applied.

Example 10:

SL: “...While a mother, once her baby starts crawling, returns to become the maid for her husband....."

TL: “... while the mother, as soon as the baby can crawl, once again becomes her husband's slave..."

The adverb 'juga' in the SL serves to add information that the task of women in villages is to work like men, besides taking care of households and children. In the TT, the function stating that there is additional information is not explicitly stated. The translator let this adverb implicit. Implicitation technique in the case above is optional since the sentence is still acceptable if it is made explicit.

\subsubsection{Addition}

The translation technique is applied when a translation needs the addition of a message to make the translation possess higher readability. The addition of information is obligatory since the information in the ST is not well understood by the target readers. Whereas this addition technique may also be optional since the addition of information is merely a style of the translator. There were nine additional techniques applied in expressions containing gender discrimination. This includes $1.91 \%$ of the total data on translation techniques.

Example 11:

SL: "Kalau perempuan Pribumi sudah begitu kurang ajar, kata satu pihak, apa pula jantannya?"

TL: "If Native women were already starting to behave so impudently, then imagine what we can expect from their men!"

The word 'starting' evaluates the verb 'to behave' in the TT. In the ST, this message does not exist. The addition of a message evaluating this verb serves to mark when a behavior is done. The translation above is optional since without such an addition, the translation is still accurate and easy to understand. 


\subsubsection{Transposition}

There were eight transpositions applied in translating expressions containing gender discrimination. This covers $1.70 \%$ of the total translation techniques applied. The transposition technique shifts the grammars in the SL. It is often used to improve the TT readability. The following is presented an example of data applying transposition.

Example 12:

SL: "Tinggal menunggu datangnya suami saja kok banyak benar yang dilakukan?" TL: "What else is there what you want? All you have to do is wait for a husband to come along, but you are out there doing all sort of things."

In the example above, the form of the phrase 'banyak benar yang dilakukan' is shifted into an intact sentence 'you are out there doing all short things.' The shift is the level one, from a lower level, a phrase, unto a high level, a clause. The transposition technique is obligatory since it is a part of a complex sentence with two clauses connected by the conjunction 'and'.

\subsubsection{Reduction}

The reduction technique is a translation technique where message content reduction occurs in the TT. This reduction technique may occur inadvertently because of specific considerations. For instance, it is too taboo or inappropriate with the TL's cultural rules. There were six data on the reduction technique applied in translating expressions containing gender discrimination. The following are presented examples:

Example 13:

SL: "Hartawan pribumi suka mengumpulkan bini dengan alasan membantu perempuan yang dijadikan bininya."

TL: "The natives collected wifes with the excuse that the were doing it to help out the women they married."

There is one message in the above data which is reduced in the translation. The phrase 'hartawan pribumi' in the ST is merely translated into 'the natives'. The word 'hartawan' is not translated. This reduction certainly shows that as if the doer of this behaviour is all natives. The reduction of a message affects the low total number of messages conveyed into the TL.

\subsubsection{Compensation}

The compensation technique moves a message in the ST into a different place in the TT. This translation technique is often used to improve translation acceptability. Six data were applying the compensation translation technique or $1.27 \%$ of the total number of 
translation techniques applied. The following is presented two examples of data using the compensation translation technique

Example 14:

SL: "Jangankan pribumi, Tuan, monyet pun bila berjuang untuk datangnya keadilan untuk kami, tentu kami terima."

TL: "Meneer, if a monkey were to join our strugle for justice, we would accept him, let alone Natives"

The word 'Tuan' in the ST addresses Pangemanan, an indigenous person working in the Dutch East Indies government. The addressing word in the ST is placed in the middle of the sentence. In the TT, the word 'tuan' which is translated into 'Meneer' is moved into the beginning of the sentence. This movement is a compensation translation technique since the message is moved into a different position in the TT. In this case, this compensation technique is optional. This compensation technique is optional because a translation is still accurate and acceptable without such a movement.

\subsubsection{Discursive Creation}

A discursive creation technique is a translation technique where the translator fails to transfer the message existing in the ST. This technique exists because the translator fails to understand the ST as a whole, or the translator may fail to understand the context of the sentence. Five discursive creation techniques were found in the data on sentences containing gender discrimination or $1.05 \%$ of the total number of the translation techniques. The following is presented with two examples of data applying the discursive creation technique.

Example 15:

SL: "Prinses tetap tidak membuka mulut sebagaimana mestinya wanita Hindia di hadapan seorang pria yang bukan muhkrim."

TL: "Princess remained silent as was the custom for women in the presence of a male who was not a close relative."

Muhrim coming from an Arabic word, means siblings or foster-brothers that cannot marry one another. Close relatives do not always mean muhrim, like cousins. In the TL, 'muhkrim' is translated into "a close relative' that has a different meaning. In this case, the translator failed to find a proper equivalence in English and did not use a proper translation technique, for instance, by describing it. 


\subsubsection{Pure Borrowing}

A pure borrowing technique is mainly applied for something cultural. Names, concepts or cultural items that cannot be found in terms of their equivalence in the TL will be borrowed as a whole by the translator to convey the same idea or concept in the TL. There were two data of sentences containing gender discrimination applying pure borrowing technique. The following is presented one of the data adopting the translation technique.

Example 16:

SL: "Siti Sundari adalah seorang perawan yang salah-tingkah, tak tahukewajarannya, seorang Belanda dalam pakaian Jawa, seorang perawan tua yang bingung mencari jodoh."

TL: "Siti Soendari was a dilinquent young woman who didn't know what was proper, a Dutch woman in a Javanese clothes, an old maid who was all in a dither because she couldn't find a man."

Siti Sundari was a Javanese name from the upper class, becoming the novel's background at that time. This name portraits a woman who is not from ordinary people. In the TL, this name is still maintained without any change because certainly, the translators cannot replace it using the name from Western culture to portrait the figure from Javanese. This pure borrowing technique is obligatory to maintain the cultural setting of place and time that become the social setting of these novels.

\subsubsection{Deletion}

The Deletion technique omits all messages in the ST. This technique makes the TT lose essential information and fail to become a text equivalent to the ST. There were two data of sentences containing gender discrimination applying the deletion technique. There was $0.42 \%$ of the total number of translation techniques applied. The following is presented one of the examples of data using the deletion technique.

Example 17:

SL: "Gadis-gadis kami barulah bebas kalau ada seorang lelaki datang dan mengambilnya jadi istri satu-satunya atau yang kesekian kemudian bercerai."

TL: “

The deletion technique discards all messages in the ST about the girls' destiny in Java under the men's power at that time. It is important information for all buildings of ideas being developed in these novels. However, the translator deleted all this message to destroy the building of the idea of women's destiny described. 


\subsubsection{Generalization}

One data on a sentence contain gender discrimination applying the generalization technique or $0.21 \%$ of the total number of the translation techniques applied. This technique takes a more general term for a more specific term in the SL. It is used when no specific term in the TL is found such that in the ST.

Example18:

SL: "Siti Sundari adalah seorang perawan yang salah-tingkah, tak tahukewajarannya, seorang Belanda dalam pakaian Jawa, seorang perawan tua yang bingung mencari jodoh."

TL: "Siti Soendari was a dilinquent young woman who didn't know what was proper, a Dutch woman in a Javanese clothes, an old maid who was all in a dither because she couldn't find a man."

The word 'perawan' in Indonesia does not only have the meaning of a young woman. It also means someone who has not got married or in a more specific term, someone who has never had sexual intercourse. In English, the closest equivalence is 'virgin'. In English translation, this word is replaced with 'young woman'. The translator used a more generic term for the term, which is more specific in the SL.

\subsubsection{Particularization}

It is the opposite of generalization; particularization looks for the equivalence of a term in SL into the one which is more specific in the TL. It is done if a proper equivalence of the word in the SL is not found in the TL. Particularization is sometimes also applied to clarify the context of a speech or an expression. One data on a sentence contain gender discrimination applying the generalization technique or $0.21 \%$ of the total number of the translation techniques applied.

Example 19:

SL: "Adik Sinyo hanya perempuan."

TL: "Your sister is just a girl."

The word 'adik' in ST which is neutral in gender is translated into 'sister' with special meaning in certain gender. The application of this particularization technique in the data above makes the translation more natural and compatible with the way the language conveys the message. 


\section{DISCUSSION}

This research showed that the form of gender discrimination in the three novels was subordination, stereotype, marginalization, workload, and violence. Subordination is the most dominant gender discrimination. This result is in line with other research results confirming that the position of women was lower than that of men and, therefore, women were inappropriate with becoming leaders for men (El Aissi, 2020; Kurnia, Nurgiyantoro, \& Fitri, 2021). Women could merely become the leaders of their fellow women, even during the Dutch colonial period. The women subordination occurred from the gender-based work division Fatmalia et al., (2012) and Ojah, (2018) related to the function of women as mothers. Their ability is used to limit their roles as carrying out domestic chores and taking care of children, a type of jobs that do not bring income and gradually leads them as unproductive workforce and does not contribute to the development process.

Moreover, a robust patriarchal culture among the Javanese community (Sudarso, Keban, \& Mas'udah, 2019), the Dutch company government (Gill \& Toms, 2019), and the global community (Adisa et al., 2019; Nutsukpo, 2020) improve men's superiority over women in personal life, family, community and state life. Likewise, a religious teaching factor supporting that men are superior than women in all religions in the world becomes the reason why the subordination dominantly occurs (Mufidah, 2017; Sudarso et al., 2019; Udoh, Folarin, \& Isumonah, 2020) in various fields. In politics, for example, a view that politics is complicated, full of debates, and needs an intelligent mind is assumed to be the world of men instead of women. This causes the public area to be possessed by men while the domestic site to be owned by women. Minimum achievement of $30 \%$ for House of Representative/Regional House of Representative to be occupied by women in various regions in Indonesia and the world is not achieved. In economics, there is still low recognition for women when they succeed in becoming economic actors since society considers that economic activities women conduct is merely a side job instead of prestigious jobs as men do. In education, there is a thought that women go to school to read and write since they will become housewives in the end. This significantly inhibits women in villages to access to study in higher education.

Similarly, inequality in access to education also occurs in Higher Education, so that unconsciously a division of specific majors has occurred. For instance, the major in engineering is dominated by male students while female students dominate in social sciences or economics. These research results imply that men and women should get equal rights in 
any field, especially in education. In the field of education, an educator is not allowed to distinguish his students based on gender.

The research result also shows that gender discrimination is translated using established equivalence, explicitation, modulation, paraphrase, implicitation, transposition, reduction, compensation, discursive creation, pure borrowing, generalization and particularization. Among the techniques, the established equivalence is the most dominant translation technique in this present research. It means that the translators are successful in transferring the intention of the SL into the TL well. Nida and Newmark stated that a translation might be said to be good if the intention of the SL may be conveyed accurately in the TL (Fengling, 2017). Although established equivalence is dominantly used, reduction, discursive creation and deletion translation techniques are also found in this research. This means that one data is showing inaccurate messages when they are transferred into the TL. This implies that the level of the translators' circumspection in rendering expressions containing discrimination in the novels should be improved so that the use of reduction, deletion and discursive creations may be avoided.

\section{CONCLUSION}

Gender discrimination is a general phenomenon occurring worldwide and may be found in everyday reality or novels. In the novels Anak Semua Bangsa, Rumah Kaca, and Jejak Langkah karya Pramoedya Ananta Toer, these research results show that gender discrimination consists of 5 (five) matters: subordination, stereotype, marginalization, workload, and violence. Among them, subordination is the most dominant gender discrimination found. Similarly, gender discrimination is translated using 14 translation techniques: established equivalence, explicitation, modulation, paraphrase, implicitation, addition, transposition, reduction, compensation, discursive creation, pure borrowing, deletion, generalization, and particularization. Although this research has studied the relationship between gender discrimination and translation technique, some limitations in this research may be followed up in further research. Further investigations should examine the translation of these three novels from the perspective of translation shifts and evaluation. 


\section{REFERENCES}

Fatmalia, W. A., Thahar, H. E., \& Nurizzati, N. (2012). Bias gender dalam novel Bumi Manusia karya Pramoedya Ananta Toer: Kajian Feminisme. Jurnal Bahasa dan Sastra UNP. 1(1), 12-21. https://doi.org/10.24036/81810

Adisa, T. A., Abdulraheem, I., \& Isiaka, S. B. (2019). Patriarchal hegemony: Investigating the impact of patriarchy on women's work-life balance. Gender in Management, 34(1), 31-38. https://doi.org/10.1108/GM-07-2018-0095

Arbain, A. (2020). Translating subtitles of becoming Jane Film: A pragmatic approach. Langkawi: Journal of The Association for Arabic and English, 6(1), 17-28. http://dx.doi.org/10.31332/lkw.v6i1.1766

Agustin, E. F. F., \& Putri, E. W. (2019). Perempuan dalam novel Khadijah: Ketika rahasia Mim tesingkap karya Sibel Eraslan (Analisis gender dan agensi perempuan). EGALITA, 14(1), 1-16. https://doi.org/10.18860/egalita.v14i1.8363

Astuti, P., Mulawarman, W. G., \& Rokhmansyah, A. (2018). Ketidakadilan gender terhadap tokoh perempuan dalam novel Genduk karya Sundari Mardjuki: Kajian kritik sastra feminisme. Ilmu Budaya (Jurnal Bahasa, Sastra, Seni Dan Budaya), 2(2), 105-114.

Badio, S., Nurgiyantoro, B., \& Hartono, H. (2019). Nilai Perjuangan dalam Novel Arus Balik Karya Pramoedya Ananta Toer. Indonesian Language Education and Literature, 5(1), 33-46. https://doi.org/10.24235/ileal.v5i1.3723

Bagtayan, Z. A. (2021). Analisis sosiologis novel Bukan Pasar Malam karya Pramoedya Ananta Toer. Ideas: Jurnal Pendidikan, Sosial, Dan Budaya, 7(1), 33-46. https://doi.org/10.32884/ideas.v7i1.329

El Aissi, H. (2020). Moroccan women's writings: Rethinking their female body and sexuality. Journal of International Women's Studies, 21(2), 53-66. Retrieved from https://www.scopus.com/inward/record.uri?eid=2-s2.085087979929\&partnerID=40\&md5=6c67bd5802b7e4abbde0fddc782bae17

Farhana RM, F., \& Aflahah, A. (2019). Kolonialisme dan nasionalisme dalam novel Bumi Manusia karya Pramoedya Ananta Toer. GHANCARAN: Jurnal Pendidikan Bahasa Dan Sastra Indonesia, 1(1), 10-25. https://doi.org/10.19105/ghancaran.v1i1.2946

Fengling, L. (2017). A comparative study of Nida and Newmark's translation theories. International Journal of Liberal Arts and Social Science, 5(8), 31-39.

Gill, R., \& Toms, K. (2019). Trending Now: Feminism, Postfeminism, Sexism and Misogyny in British Journalism. Journalism, Gender and Power, (pp. 97-112). Routledge.

Hafid, A. (2017). Diskriminasi bangsa Belanda dalam novel Salah Asuhan karya Abdoel Moeis (Kajian postkolonial). Kembara: Jurnal Keilmuan Bahasa, Sastra, Dan Pengajarannya, 3(2), 123-134. https://doi.org/10.22219/kembara.v3i2.5609 
Kadhim, M. M. (2018). A comparative study of slavery and untouchability through selected literary texts: 'untouchable' by Mulk Raj Anand and 'uncle Tom's Cabin' by Harriet Beecher Stowe. Opcion, 34(85), 2637-2644.

Kholifatu, A., \& Tjahjono, T. (2020). Subaltern dalam novel Arok Dedes karya Pramoedya Ananta Toer: Kajian poskolonial Gayatri Spivak. Stilistika: Jurnal Pendidikan Bahasa dan Sastra, 13(1), 120-126. https://doi.org/10.30651/st.v13i1.3656

Kurnia, N. I., Nurgiyantoro, B., \& Fitri, C. E. (2021). The othering of majority and minority groups in lessing and ajidarma's literary works: A postcolonial analysis. GEMA Online Journal of Language Studies, 21(1), 76-88. https://doi.org/10.17576/gema-2021-210105

Mufidah, C. (2017). Complexities in dealing with gender inequality: Muslim women and mosque-based social services in East Java Indonesia. Journal of Indonesian Islam, 11(2) , 459-488. https://doi.org/10.15642/JIIS.2017.11.2.459-488

Nursiah, N., \& Liusti, S. A. (2020). Tindak tutur ekspresif dalam novel Bumi Manusia karya Pramoedya Ananta Toer. Lingua Susastra, 1(2), 73-81. https://doi.org/10.24036/1s.v1i2.12

Nutsukpo, M. F. (2020). Feminism in Africa and African Women's Writing. African Research Review, 14 (1), 84-94. https://doi.org/10.4314/afrrev.v14i1.8

Ojah, E. U. (2018). Women in the kitchen of philosophy: Re-asking the questions of African philosophy. In African Philosophy and the Epistemic Marginalization of Women, 207218. https://doi.org/10.4324/9781351120104

Rahman, H. (2016). Diskriminasi gender perempuan Papua dalam novel Isinga karya Dorothea Rosa Herliany. BAHASTRA, 35(2), 41-49. https://doi.org/10.26555/bahastra.v35i2.4860

Rejo, U. (2012). Diskriminasi kelas dan gender terhadap perempuan Bali dalam novel Tarian Bumi karya Oka Rusmini. LiNGUA: Jurnal Ilmu Bahasa dan Sastra, 6(3), 241-243. https://doi.org/10.18860/ling.v6i3.1465

Risnawati, R., Anshari, A., \& Abidin, A. (2017). Pertentangan dan kesadaran kelas dalam novel Bumi Manusia karya Pramoedya Ananta Toer (Pendekatan Teori Marxis). RETORIKA: Jurnal Bahasa, Sastra, dan Pengajarannya, 9(1), 68-79. https://doi.org/10.26858/retorika.v9i1.3795.

Santaemilia, J. (2012). Translating international gender-equality institutional/legal texts: The example of'gender'in Spanish. Gender \& Language, 6(2), 75-96.

Sari, L. P. (2019). Diskriminasi gender dalam novel Terusir karya Hamka melalui perspektif Sara Mills. BASINDO : Jurnal Kajian Bahasa, Sastra Indonesia, dan Pembelajarannya, 3(1), 55-64. https://doi.org/10.17977/um007v3i12019p055 
Sariban, S., \& Marzuqi, I. (2015). Menemukan keindonesiaan dalam novel-novel Pramoedya $\begin{array}{llll}\text { Ananta } & \text { Toer. } & \text { ATAVISME, } & \text { 18(2), }\end{array}$ https://doi.org/10.24257/atavisme.v18i2.112.159-169

Setyorini, R. (2017). Diskriminasi gender dalam novel Entrok karya Okky Madasari: Kajian feminisme. Jurnal Desain, 291-297. https://doi.org/10.30998/jurnaldesain.v4i03.1866

Sudarso, Keban, P. E., \& Mas'udah, S. (2019). Gender, religion and patriarchy: The educational discrimination of coastal madurese women, East Java. Journal of International Women's Studies, 20(9), 2-12.

Sulaeman, A., Rohim, A., \& Muttaqien, Z. (2020). Language variation found in the novel Bumi Manusia by Pramoedya Ananta Toer. Journal of English Language and Literature (JELL), 5(01), 53-62. https://doi.org/10.37110/jell.v5i01.95

Suresh, P., \& Anuradha, P. (2018). A critical study of women oppression on Alice Walker's major novels. Eurasian Journal of Analytical Chemistry, 13(4), 95-102.

Suwaed, M. Y. (2017). The exploitation of women and social change in the writing of Nawal El-Saadawi. Journal of International Women's Studies, 18(4):233-246.

Udoh, O. D., Folarin, S. F., \& Isumonah, V. A. (2020). The influence of religion and culture on women's rights to property in Nigeria. Cogent Arts and Humanities. https://doi.org/10.1080/23311983.2020.1750244

Unsriana, L. (2014). Diskriminasi gender dalam novel Ginko karya Junichi Watanabe. Lingua Cultura. https://doi.org/10.21512/lc.v8i1.441

Wang, Y., Yu, X., \& Chen, Q. (2020). Translation and negotiation of gender stereotypes: Metamorphosis of female characters in the English version of a Chinese classical novel. Perspectives, 28(5), 702-716. https://doi.org/10.1080/0907676X.2019.1663887

Wicaksono, A. (2018). Sejarah politik Indonesia dalam novel Larasati karya Pramoedya Ananta Toer. JENTERA: Jurnal Kajian Sastra, 7 (1), 20-35. https://doi.org/10.26499/jentera.v7i1.340

Winusari, N. N. (2019). Struktur naratif novel Bumi Manusia karya Pramoedya Ananta Toer: Sebuah tinjauan sosiologi sastra. Jurnal Pendidikan Dan Pembelajaran , 7(2), 34-42. 